\title{
Colonialidad, reparto de lo sensible y descolonización: una crítica rancieriana a la "opción decolonial" de Walter Mignolo *
}

\author{
Coloniality, distribution of the sensible and decolonization: a Rancierian \\ critique of Walter Mignolo's "colonial option"
}

\author{
Por: García, Juan Diego* \\ INES-CONICET/ Universidad Católica de Santa Fe (UCSF) \\ Argentina \\ Email: jdgar.92@gmail.com \\ Fecha de recepción: 29/05/2021 \\ Fecha de aprobación: 25/10/2021 \\ DOI: https://doi.org/10.30972/nvt.1725709
}

\section{Resumen}

En el presente trabajo proponemos abordar y problematizar algunos aspectos de la "opción decolonial" propuesta por Walter Mignolo. Específicamente nos interesa indagar cómo la articulación de dos categorías centrales de su pensamiento, "diferencia colonial" y "geopolítica del conocimiento", da lugar a una política decolonial con una fuerte impronta identitaria que busca des-prenderse de todo legado moderno. Para profundizar esta problematización, y como principal aporte del escrito, proponemos retomar la noción de "reparto de lo sensible" (partage du sensible) del filósofo argelino-francés Jacques Rancière para ver si es posible y qué implicancias tendría pensar la colonialidad desde esta perspectiva. Trazar este vínculo conceptual nos permitirá elucidar por qué el dispositivo teórico de Mignolo, al estabilizar una relación entre modo de ser, lugar y pensamiento, reproduce cierta lógica colonial y también puede abrirnos a una compresión de la decolonialidad que no

\footnotetext{
* El presente trabajo es fruto de las problematizaciones que ha abierto la actual investigación doctoral del autor, cuyo proyecto se titula "Historia, tiempo y política en el pensamiento de Jacques Rancière" * Profesor de Filosofía por la Universidad Nacional del Litoral. Becario doctoral de CONICET del Doctorado en Humanidades (Filosofía) de la UNL.Profesor de la Universidad Católica de Santa Fe.
} 
Colonialidad, reparto de lo sensible y descolonización: una crítica rancieriana a la "opción decolonial" de Walter Mignolo

descanse en un sesgo identitario. Para explorar este último punto pondremos en diálogo el modo en que Rancière piensa los procesos de subjetivación política con una práctica decolonial específica: la apropiación de los símbolos y discursos de la Revolución Francesa que llevaron a cabo los esclavos negros en la gesta revolucionaria haitiana.

Palabras clave: diferencia colonial - geopolítica del saber - colonialidad reparto de lo sensible - igualdad

\section{Abstract}

In this paper we propose to address and problematize some aspects of the decolonial option of the argentine semiologist Walter Mignolo. Specifically, we are interested in investigating the articulation of two central categories of his thought; "colonial difference" and "geopolitics of knowledge" and how give rise to a politics of identity. To deepen this problematization, and as the main contribution of the writing, we propose to rebuild the notion partage du sensible of Jacques Rancière in order to see if it is possible and what implications would think coloniality in this terms. We argue that drawing this conceptual link will allow us to elucidate why Mignolo's theoretical device, by stabilizing a relationship between way of being, place and thought, reproduces a certain colonial logic and can also suggest us to think decolonization without an identity imprint. To explore this last point, we will briefly return to the way in which Rancière thinks about the processes of political subjectivation in order to put him in dialogue with a specific decolonial practice: the appropriation of the principles of the French Revolution than by black slaves in the Haiti independence.

Keywords: Colonial difference - geopolitics of knowledge - coloniality distribution of the sensible - equality 
Cómo citar este artículo:

APA: García, J. D. (2021). Colonialidad, reparto de lo sensible y descolonización: una crítica rancieriana a la "opción decolonial" de Walter Mignolo. Nuevo Itinerario, 17 (2), 27-65. Recuperado de: (agregar dirección web)

\section{Introducción}

En su bello libro Aquí América Latina, una especulación, Josefina Ludmer señala que pensar desde y sobre América Latina supone el riesgo de asumir cierta "posición estratégica crítica" que permita articular un nuevo lenguaje y nuevas imágenes a quienes "somos los que llegaron tarde al banquete de la civilización” (Ludmer, 2010, p. 10-11). Para la autora se trata, no de considerar el lugar desde el que inevitablemente pensamos como un privilegio de mirada, sino como una mera condición para imaginar o especular nuevas sensibilidades; ficcionalizar otros mundos posibles. Esta conciencia conflictiva de lugar pareciera ser una de las notas que atraviesa, de modos heteróclitos, discontinuos y, sobre todo, contradictorios toda la tradición filosófica americana. En las últimas décadas, la emergencia del autodenominado colectivo Modernidad/Colonialidad, ha insistido en pensar y construir un lugar de enunciación crítico, estratégico y decolonial, retomando las herencias teóricas y prácticas de Nuestra América (Castro Gómez y Grosfoguel, 2007). Los estudios decoloniales han tenido un fuerte impacto y múltiples resonancias en distintos ámbitos académicos, militantes, culturales y políticos de la región, así como en otras latitudes. En este sentido, sus reflexiones y categorías constituyen un inmejorable material para analizar, revisar y discutir a la hora de pensar nuestro locus de pensamiento, así como las posibilidades de especular otros futuros posibles.

En el presente trabajo proponemos retomar críticamente algunos aportes de la "opción decolonial" propuesta por una de las figuras más destacadas de este grupo; Walter Mignolo, y tensarla en cierto desacuerdo con algunas nociones del filósofo argelino-francés Jacques Rancière. Para ello, en primer lugar, contextualizaremos brevemente el pensamiento de Mignolo en el horizonte teórico que abrieron los estudios decoloniales. Luego, en el segundo apartado, nos centraremos en el cruce de dos conceptos importantes de su pensamiento: "diferencia colonial" y "geopolítica del 
conocimiento". Mientras que la primer categoría busca pensar la alteridad y la potencia de los colonizados (les damnés de la terre), la segunda alude a la perspectiva epistémica que abraza el autor, perspectiva que permitiría dar cuenta de un modo positivo de esta alteridad. Nos interesa exponer por qué la relación entre ambas tiene consecuencias problemáticas, puesto que no solo -como han señalado algunos críticos- conduce a un privilegio epistémico por parte de quienes han sufrido la "herida colonial", sino que lleva a pensar los procesos de descolonización bajo la impronta de una "identidad en la política" (identity in politics) que supone un des-prendimiento de todo el legado emancipatorio moderno.

En el tercer apartado, y como principal aporte de nuestro escrito, proponemos introducir la noción de "reparto de lo sensible" (partage du sensible) de Rancière para ver si es posible pensar la colonialidad retomando esta perspectiva. Nuestra hipótesis es que trazar este vínculo conceptual puede permitirnos elucidar por qué ciertos aspectos del dispositivo teórico que Mignolo elabora -al estabilizar una relación entre modo de ser, lugar y pensamiento- reproduce cierta lógica colonial, a la vez que puede sugerirnos pensar los procesos de descolonización más allá del sesgo identitario de lo "propio". Para esto último, en el cuarto apartado, retomaremos y pondremos en diálogo el modo en que Rancière piensa los procesos de subjetivación política (como procesos de desidentificación y prácticas de la igualdad), con la apropiación del discurso y los símbolos de los franceses que llevaron a cabo los esclavos en la Revolución Haitiana. Intentaremos mostrar cómo esta práctica decolonial, más que un des-prendimiento del legado moderno, consistió en una re-apropiación y torsión del mismo, capaz de reconfigurar sensiblemente un reparto colonial.

Al traer al diálogo la propuesta rancieriana y desde allí esbozar una crítica a la "opción decolonial" de Mignolo no pretendemos desconocer, ni minimizar la problemática de la colonialidad y su vigencia. Creemos que el cruce con ciertas ideas de Rancière, no solo sirve para señalar aspectos problemáticos de esta propuesta específica (que en general ya han sido marcados por otros autores), sino que puede contribuir a pensar de un modo distinto la sujeción colonial y, sobre todo, las prácticas y procesos de descolonización. En este sentido, un interés lateral del trabajo es 
correrse de cierto prejuicio que opera muchas veces en los estudios decoloniales, y que en la obra de Mignolo adquiere un justificativo teórico, de considerar como eurocéntrico y colonial cualquier producción teórica proveniente del Viejo Continente. Más bien, creemos oportuno mostrar cómo posibles apropiaciones de ciertos legados modernos, pueden ser fructíferos y necesarios para especular y articular prácticas decoloniales desde este lugar de fronteras permeables y móviles que llamamos Nuestra América.

\section{Mignolo y el "giro decolonial": la colonialidad, la cara oculta y oscura de la modernidad}

Walter Mignolo (1941) es un semiólogo y filósofo argentino radicado desde los años '70 en los Estados Unidos, donde desde algunas décadas, se desempeña como docente e investigador en la prestigiosa Universidad de Duke. A partir de la publicación de su obra, The Darker Side of the Renaissance: Literacy, Territoriality and Colonization (1995) su nombre comienza a cobrar relevancia en el pensamiento poscolonial a nivel global. Por su parte, lejos de quedar enclaustrado en la academia norteamericana, Mignolo fue estableciendo contactos con instituciones y grupos de intelectuales latinoamericanos, que le permitieron ir enhebrando una red de pensamiento que confluirá en el proyecto teórico conocido como el "grupo Modernidad/Colonialidad". Junto a Aníbal Quijano (fallecido en 2018) y Enrique Dussel, Mignolo es considerado como uno de sus principales referentes.

Este proyecto, también conocido como "giro decolonial", se conformó a partir de distintos encuentros académicos que articularon Universidades latinoamericanas y anglosajonas desde mediados de 1990 y fue consolidándose de manera definitiva en la primera década del siglo. El grupo o "red" -como prefiere denominarla Castro-Gómez (2019)- está conformada por un conjunto de intelectuales latinoamericanos pertenecientes a distintos campos disciplinares de las ciencias sociales y humanas que

\footnotetext{
${ }^{1}$ Para una genealogía más detallada de la conformación del grupo remitimos al prólogo de CastroGómez y Grosfoguel (2007).
} 
retoman y abordan el problema de la herencia colonial de un modo novedoso ${ }^{2}$. Si bien este proyecto intelectual se inserta, en alguna medida, en el horizonte que abrieron los estudios postcoloniales y subalternos de la India, los autores del giro decolonial se ocupan de tomar una "distancia creativa" con estos, enfatizando que sus reflexiones retoman la experiencia histórica latinoamericana y sus tradiciones de pensamiento emancipatorias para pensar el problema de la colonialidad y su vigencia en nuestras sociedades actuales. (Blanco, 209, p.89)

La principal intuición teórica del grupo, esbozada bajo la categoría de "colonialidad", consiste en rechazar que con las independencias políticas de los Estados americanos en el siglo XIX la etapa colonial haya llegado a su fin, y consideran que es preciso analizar cómo las formas, mecanismos y contenidos de la "matriz colonial del poder" han mutado pero aún su lógica de estructuración desigualitaria y racista se mantiene vigente. Si el colonialismo alude al proceso y experiencia de conquista y a la administración jurídico-política de los territorios, la colonialidad busca pensar una lógica estructural global más profunda y tentacular que se asienta en ese proceso, pero lo excede. Pretende así trazar una gran continuidad entre "Ios tiempos coloniales y los mal llamados tiempos poscoloniales" (Castro-Gómez y Grosfoguel, 2007, p.19).

Para dar cuenta de estas continuidades estos autores retoman los aportes pioneros de Aníbal Quijano, condensados en su categoría de "colonialidad del poder", que les permite tener una mirada multifacética del hecho colonial y su vigencia (Restrepo y Rojas, 2010). En sus investigaciones, Quijano sostuvo que la colonialidad del poder operó a partir de estructurar un sistema de clasificación social basado en la idea de "raza/etnia" que estableció diferencias inconmensurables entre las identidades de los colonizados y colonizadores (Quijano, 2000, p.122). Estas diferencias se traducían en la legitimación de un orden social jerárquico, que organizaba y distribuía a los sujetos en posiciones, ocupaciones y obligaciones dando lugar a clases sociales racializadas y a diversas formas de explotación de la fuerza de trabajo. En este sentido,

\footnotetext{
${ }^{2}$ Algunos de los nombres destacados que componen esta constelación decolonial son: Edgardo Lander, Arturo Escobar, Santiago Castro-Gómez, Catherine Walsh, Ramón Grosfoguel, Rita Segato, Nelson Maldonado Torres, Eduardo Restrepo, Zulma Palermo, entre otros.
} 
a partir de sus diversos aportes, los estudios decoloniales intentan ofrecer una "analítica del poder colonial" que logre dar cuenta del complejo juego de relaciones asimétricas (económicas, sociales, raciales, genéricas, culturales y epistémicas), las formas de violencias y despojos coloniales del pasado y aún persistentes, a escala global y local. Vale destacar que también proponen esbozar un "pensamiento prospectivo" capaz de abrir una "opción decolonial" (Mignolo, 2015, p.84). De este modo, el interés analítico de las relaciones coloniales se articula con una motivación política explícitamente presente, aunque con distintas variantes y matices en los diversos autores ${ }^{3}$.

En uno de sus textos más importantes, La idea de América Latina, la herida colonial y opción decolonial (2005), Mignolo se encarga de exponer las premisas que comparte (y que ha contribuido a elaborar) con el grupo Modernidad/Colonialidad. Retomando los aportes de Dussel, una de las referencias principales en sus textos, Mignolo reconoce la importancia fundacional de la experiencia colonial en América para el desarrollo de la modernidad y el capitalismo europeo (Ilustración y Revolución industrial). Recuperando el "mito de la Modernidad" dusseliano, plantea la idea de que esta es un proceso con "dos caras"; una de ellas es la que sustenta la retórica del progreso, la racionalidad y la ilustración, y la otra cara, oculta, es la colonialidad (Dussel, 2003). La modernidad y sus prédicas de salvación y liberación, esconden detrás de cada enunciado emancipatorio una acción de dominio y opresión que hizo posible el establecimiento de las relaciones coloniales de servidumbre y esclavitud. En este sentido, como recurrentemente plantea Mignolo en sus textos, la colonialidad es la "cara oculta" y "oscura" de la modernidad.

Sin embargo, hay una dimensión oculta de acontecimientos que estaban teniendo lugar al mismo tiempo, tanto en el campo de la economía como en el del conocimiento: la prescindibilidad de la vida humana (por ejemplo, los esclavos

\footnotetext{
${ }^{3}$ Esta diversidad interna, también presente a nivel teórico y epistemológico -no exenta de tajantes desacuerdos al interior del propio grupo- es un aspecto que no puede soslayarse a la hora de tener una comprensión rigurosa de los estudios decoloniales. Desde ya advertimos que muchas de las ideas de Mignolo que a continuación reconstruiremos y problematizaremos, no necesariamente son compartidas por otros miembros del grupo.
} 
Colonialidad, reparto de lo sensible y descolonización: una crítica rancieriana a la "opción decolonial" de Walter Mignolo

africanos) y de la vida en general desde la Revolución Industrial hasta el siglo XXI (...) Así pues, tras la retórica de la modernidad había una realidad oculta: las vidas humanas pasaban a ser prescindibles en aras de incrementar la riqueza, y dicha prescindibilidad se justificaba a través de normalizar la clasificación racial de los seres humanos." (Mignolo, 2015, p.30)

Detrás del luminoso discurso moderno, humanista e ilustrado, el trasfondo oscuro que discurre en la modernidad es la colonialidad. Esta es una de las tesis centrales del "giro decolonial": la colonialidad, no es un hecho contingente, accidental o un fenómeno derivado de la modernidad, sino que le es constitutiva. No hay modernidad sin colonialidad. Si bien en distintos autores del grupo esta tesis cobra distintos matices y consecuencias, en Mignolo particularmente encontramos que el énfasis en este vínculo lo lleva a impugnar como colonial todo legado moderno y a proponer un des-prendimiento del mismo. "La modernidad necesita la colonialidad para instalarse, construirse y subsistir. No hubo ni habrá modernidad sin colonialidad" (Mignolo, 2003, p.35). Sobre esta impugnación de la modernidad volveremos más adelante ya que compartimos con otros autores (Castro-Gómez, 2019 p.237, Polo Blanco y Gómez Betancur, 2019) que es uno de los callejones sin salida de la propuesta de Mignolo.

\section{Diferencia colonial y geopolítica del conocimiento: hacia una política de identidad}

Uno de los aportes principales y originales de Mignolo a los estudios decoloniales es el concepto de "diferencia colonial" (Restrepo y Rojas, 2010, p.33). Como han señalado algunos críticos, esta categoría no está exenta de dificultades que es preciso analizar (Salvatore, 2006, Velázquez Castro, 2008 y Castro Orellana, 2020). Nos interesa mostrar que uno de sus aspectos más problemáticos, que conduce a Mignolo a plantear cierto sesgo identitario en su propuesta decolonial, no puede entenderse sin su articulación con la "geopolítica del conocimiento" que sostiene el autor. 
En términos generales podríamos decir que la "diferencia colonial" hace referencia a la alteridad de los colonizados: el conjunto de experiencias, creencias y prácticas diferenciales respecto del colonizador que son sistemáticamente invisibilizadas e inferiorizadas en el imaginario occidental. En el cuidadoso rastreo que propone Rodrigo Castro Orellana (2020) de este concepto, destaca que su presencia en los diversos textos de Mignolo presenta distintos modos de entenderla, distintos usos, que a veces se encuentran en relación y que también exhiben cierta ambigüedad. Por momentos Mignolo estrecha esta noción con la idea de colonialidad del poder recién esbozada:

La colonialidad del poder es el dispositivo que produce y reproduce la diferencia colonial. La diferencia colonial consiste en clasificar grupos de gentes 0 poblaciones e identificarlos en sus faltas o excesos, lo cual marca la diferencia y la inferioridad con respecto a quien clasifica. (Mignolo, 2003, p.39)

En este sentido, la "diferencia colonial" alude al resultado de los múltiples mecanismos de subalternización e inferiorización de las culturas, saberes y sujetos, que desde el siglo XVI al presente, la matriz colonial de poder ha instaurado, producido y reproducido. De allí que Mignolo señale en otro texto: "La diferencia colonial actúa convirtiendo las diferencias en valores y estableciendo una jerarquía de seres humanos, ontológicamente y epistémicamente" (Mignolo, 2015, p.41). Esta "diferencia" es la exterioridad construida por la retórica colonial moderna para reafirmar una serie de jerarquías que suponen la superioridad del blanco imperial en un sistema de clasificación racial.

Como vemos, en este primer sentido, la alteridad de los colonizados refiere a una diferencia producida a partir de una serie de dispositivos sedimentados del poder colonial. Estos dispositivos configuran un sistema de jerarquías y diferencias que constituye el espacio relacional donde esta alteridad se articula desigualmente con otras identidades. Esta noción de "diferencia colonial” es cercana a la idea de Quijano en torno a la producción y codificación de diferencias por la lógica de la raza, que 
opera como condición de posibilidad y legitimación de la subalternización de ciertos sujetos y sus culturas.

Ahora bien, en los textos de Mignolo, la "diferencia colonial" no es solo el espacio donde se pone en juego el poder colonial, sino también donde emerge la resistencia, el "pensamiento fronterizo" (border thinking) y los procesos de decolonialidad. El autor afirma (2007):

El pensamiento fronterizo surge de la diferencia imperial/colonial de poder en la formación de las subjetividades. De ahí que el pensamiento fronterizo no sea connatural a un sujeto que habita la casa del imperio, pero sí lo sea en la formación de sujetos que habitan la casa de la herida colonial (p.90. sub. nuestro)

En varios pasajes de sus escritos, la "diferencia colonial" alude al ethos de los colonizados y al tipo de experiencia, conocimientos y prácticas de resistencia que se desarrollaron en los márgenes (bordes/fronteras) del imaginario occidental moderno (Mignolo, 2007). Estos saberes, históricamente marginados, abren la posibilidad de una crítica y des-prendimiento del proyecto moderno-colonial: "El pensamiento decolonial presupone siempre la diferencia colonial" (Mignolo, 2007, p.29). De este modo, para Mignolo un reconocimiento positivo de la "diferencia colonial" -a la que le es connatural el "pensamiento fronterizo"- es una de las claves para llevar adelante los procesos decoloniales.

Entendemos que el carácter problemático de esta noción no necesariamente se presenta en esta ambigüedad, dado que ambas acepciones, si bien presentan cierta tensión no son contradictorias; es lícito pensar que la "diferencia colonial" es a la vez un resultado de procesos de subalternización, y que también desde ese lugar emerjan ciertas formas de pensar alternativas y prácticas de resistencia que propongan otros modos de relaciones y otras formas de reconocimiento. Ahora bien, sí nos resulta problemático la relación que establece el autor entre esta categoría y la idea de "geopolítica del conocimiento", porque parecería ubicar a la "diferencia colonial" 
(modo de ser), en un lugar de enunciación propio, adjudicándole una experiencia (la "herida colonial") y una potencia de pensamiento ("pensamiento fronterizo fuerte").

Acercarse a la categoría de "geopolítica del conocimiento" resulta central para entender la perspectiva epistémica que sustenta el proyecto decolonial de Mignolo. La misma se interesa, no tanto por los enunciados en sí, sino por "la forma de enunciación", entendida, como el lugar y la experiencia del sujeto de la enunciación (Mignolo, 2010, p. 10). La geopolítica del saber se pregunta por quién habla y los supuestos materiales e históricos de los distintos lugares de enunciación. En este sentido, parte del axioma de que todo sujeto cognoscente "está implicado corpo y geopolíticamente con el objeto a conocer" (2010, p.14).

Esta perspectiva habilita dos movimientos importantes en la obra de Mignolo. Por un lado, propone una vinculación entre espacio, saber y poder que hace posible una visión crítica a cualquier idea de conocimiento que no reconozca sus propias condiciones históricas de producción y circulación. Esto le permite ensayar una crítica a la idea de episteme moderna basada en una subjetividad trasparente universal, deslocalizada y neutra, que esgrime una enunciación atópica y a-corporal. En efecto, la "geopolítica del conocimiento" busca poner en cuestión todo discurso que se presente sin asumir su lugar de enunciación situado e histórico. Es preciso tener en cuenta que para los autores del "giro decolonial" la imposición eficaz del imaginario occidental moderno en parte fue posible porque se legitimó en un discurso universalista que lo autopostulaba como el único verdadero y válido, encubriendo sus propias condiciones de producción y enunciación (Castro-Gómez, 2005). La epistemología y el discurso colonial moderno negaban su particularidad y su lugar de enunciación situado, a fin de legitimar bajo un estandarte de neutralidad, su posición e imposición a los otros. De allí que los estudios decoloniales sugieran la necesidad de una "geopolítica del conocimiento" para poder dar cuenta de cómo el saber y las creencias surgen siempre de un determinado locus de enunciación, y operan o funcionan muchas veces acompañando estrategias de valoración y subvaloración de otras epistemes y cosmovisiones 
Por otro lado, la perspectiva geopolítica permitiría "abrir" la epistemología hacia los "saberes otros", deslegitimados y subalternizados por el discurso moderno. Es en este punto donde Mignolo articula explícitamente su perspectiva epistémica con "la diferencia colonial". El autor señala que la geopolítica del conocimiento "se organiza en torno a la diversificación, histórica, de las diferencias coloniales e imperiales" en el sistema-mundo moderno (2002, p. 59, trad. nuestra). Opera a partir de distinguir entre formas de conocimiento hegemónicas (imperiales) o subalternizadas (colonizadas) teniendo en cuenta precisamente de qué lugar de enunciación provienen y explorando el modo en que las primeras imponen las reglas y criterios que soslayan o relegan a las otras produciendo diversas formas de "colonialidad del saber". En este sentido, Mignolo considera que el pensamiento decolonial "tiene que adoptar un punto de vista geográfico en su historicidad e introducir en juego la diferencia colonial" (Mignolo, 2002, p.67, trad. nuestra). Esto implica "ensanchar el espacio" colonizado por la episteme moderna y entender "que un cuerpo racialmente marcado en un espacio geo-históricamente marcado, siente la urgencia o la necesidad de hablar" (Mignolo, 2010, p.10). La perspectiva geopolítica otorga entonces una visibilidad a los cuerpos racializados y abre hacia una escucha de las voces de "los desheredados de la modernidad, de aquellos para quienes sus experiencias y sus memorias corresponden a la otra mitad de la modernidad, es decir, a la colonialidad" (Mignolo, 2003, p.27).

He aquí lo que Stefan Pimmer (2007) ha señalado atinadamente como el aspecto normativo de esta perspectiva: la geopolítica del conocimiento permitiría reconocer y revalorizar aquellos saberes, creencias y cosmovisiones acalladas y marginalizadas por el discurso universalista moderno, saberes, que según Mignolo, están latentes y presentes en los cuerpos y las comunidades de los colonizados. En este sentido, lograr un des-prendimiento del saber moderno-occidental requiere no solo que se ponga en evidencia su lugar de enunciación imperial, sino que también es preciso recuperar los saberes y prácticas de la diferencia colonial: situarse "ontológicamente en el poder diferencial del racializado, en/desde las historias locales a las que le fueron negadas su potencial epistémico" (Mignolo, 2003, p. 22). 
Como puede apreciarse, desde la perspectiva geopolítica, la "diferencia colonial" se identifica con el locus de enunciación propio de quienes han padecido y padecen la experiencia colonial (lo que Mignolo denomina como herida colonial); quienes parecieran ser a su vez los únicos capaces de plantear un "pensamiento fronterizo" y una práctica política verdaderamente decolonial ${ }^{4}$. La idea de "frontera" en el pensamiento de Mignolo designa precisamente el lugar marginal, este borde externo del sistema-mundo colonial, de donde surge el pensamiento capaz de ir "más allá" de la ratio moderno-colonial.

Sandro Mezzadra y Brett Nielson en su libro La frontera como método (2013) señalan de manera crítica que "el pensamiento de Mignolo acerca de las fronteras parecería reinscribir paradójicamente la consistencia ( $y$, por lo tanto, las fronteras) de Europa y de Occidente" (p.38). En efecto, la preocupación de la geopolítica del conocimiento por delimitar claramente los lugares de enunciación lleva a que el "pensamiento fronterizo" de Mignolo se comprometa más tenazmente con la demarcación de los límites entre lo interno/externo, espacio colonial/imperial, que con el espacio heterotópico que surge de su desdibujamiento. Como recupera Castro Orellana (2020), esto se hace evidente cuando el semiólogo argentino refuerza el vínculo entre diferencia colonial, lugar de enunciación y pensamiento, al introducir una distinción entre pensamiento fronterizo débil y fuerte o al marcar insistentemente la irreductibilidad entre la diferencia colonial y la diferencia imperial (p.80). Para Mignolo algunos exponentes del pensamiento fronterizo débil o de la diferencia imperial son Las Casas, Marx, Gramsci, Nietzsche o Wallerstein. Se trata de pensadores críticos de la modernidad, pero situados en un lugar de enunciación imperial que explicaría los límites de sus reflexiones a la hora de pensar una opción decolonial. En estos casos la emergencia del pensamiento crítico no es "fruto del dolor y la furia de los desheredados mismos, sino de quienes toman la perspectiva" (Mignolo, 2003, p.28). El argentino marca explícitamente una "diferencia irreductible" entre lugar de enunciación y perspectiva, distinción que sellaría un límite rígido entre quienes han

\footnotetext{
${ }^{4}$ Sobre este aspecto apuntan las críticas de Salvatore (2006) y Castro Velázquez (2008).
} 
padecido la herida colonial y aquellos que deciden abrazar su perspectiva ${ }^{5}$. Este límite amuralla el lugar de enunciación de la diferencia colonial determinado por el tipo de experiencia (la herida colonial) y el lugar geográfico. De este modo, el pensamiento fronterizo fuerte, queda reservado a los sujetos que han experimentado la colonialidad del poder como tal; algunas de las figuras que propone Mignolo son: Guaman Poma, Quobna Cugoano, Franz Fanon, y como sujetos colectivos, las comunidades indígenas y afrodescendientes.

Entendemos que la articulación entre la perspectiva geopolítica del conocimiento y la diferencia colonial conduce en la obra de Mignolo a una suerte de territorialización del pensar basada en un vínculo directo entre ser, lugar y experiencia. Desde esta perspectiva, la diferencia colonial remitiría a una serie de subjetividades agrupadas en un lugar de enunciación y una experiencia común, capaz de desprenderse del legado occidental moderno y reivindicar un pensamiento "otro", que no sería sino el "propio". Esta potencia se encarnaría concretamente en aquellas poblaciones subalternizadas, material, cultural y epistémicamente por los procesos coloniales, cuya emergencia harían posible rehabilitar otros modos de pensar, de sentir y vivir no contaminados por la colonialidad: "el pensamiento decolonial ha estado viviendo [dwelling] en las mentes y los cuerpos de los indígenas y de los afrodescendientes" (2007a, p.46, trad. nuestra). Esta articulación entre diferencia colonial y geopolítica del saber produce una mirada identitaria y cierto esencialismo en el pensamiento de Mignolo, que como bien muestra Javier Franze (2013) radica en el lugar de enunciación específico y en la supuesta potencia diferencial que la experiencia colonial ha dado a los grupos que la han padecido.

Es evidente que para el semiólogo argentino la descolonización se vuelve un asunto de las víctimas y de una afirmación y reconocimiento de su diferencia colonial. Mignolo sostiene explícitamente que todo proceso decolonial tiene que inscribirse en

\footnotetext{
${ }^{5}$ En su artículo "The Geopolitics of Knowledge and the Colonial Difference" Mignolo se esfuerza por demostrar que la "brecha" (break) entre el pensamiento de Wallerstein y el de Dussel y Quijano se debe a que estos últimos tienen como loci de enunciación la diferencia colonial. Este lugar de enunciación dado, no solo por el lugar geográfico, sino por la experiencia de colonialidad que les permitiría no quedar atrapados en la ratio occidental moderna, como, en definitiva, y a pesar de su esfuerzo le sucede a autor del sistema-mundo.
} 
una "identidad en la política" (identity in politics) que no es sino la reivindicación y visibilización de epistemes y prácticas, de un ethos propio de los colonizados y sus saberes alternativos que rechazan al imaginario occidental.

Al vincular la decolonialidad con la identidad en la política, la opción decolonial revela la identidad oculta bajo la pretensión de teorías democráticas universales al mismo tiempo que se basa en las identidades racializadas que fueron construidas por la hegemonía de las categorías occidentales de pensamiento, historias y experiencias ${ }^{6}$. (Mignolo 2007a, p.52, traducción nuestra)

La afirmación de las identidades de los colonizados (diferencia colonial) permite un des-prendimiento de las categorías totalitarias del proyecto moderno y de su subjetividad. Des-prenderse de lo "otro" colonial para afirmar lo "propio". Ahora bien, si se sostiene que la diferencia colonial fue producida por una serie compleja de mecanismos de subalternización e inferiorización, ¿basta su mera afirmación para hacer práctico y eficaz un movimiento de descolonización que ponga en cuestión el orden colonial? Por otra parte ¿es posible y deseable des-prenderse de todo el legado moderno?

\section{Jacques Rancière: reparto de lo sensible, policía y colonialidad}

Para pensar estos problemas creemos que puede ser interesante poner en diálogo los conceptos de colonialidad y diferencia colonial con la noción de "reparto de lo sensible" (partage du sensible) que propone Jacques Rancière. Este es uno de los conceptos claves en el pensamiento del argelino-francés ya que permite, no solo abordar las relaciones entre saber, política y estética en su obra, sino también comprender su perspectiva de análisis en general. En algunas entrevistas y conferencias, Rancière inscribe a su pensamiento en la tradición "crítica" en clave

\footnotetext{
${ }^{6}$ Sobre la distinción que plantea Mignolo entre política de la identidad e identidad en la política, Franze (2013) afirma: "Si ambas se diferencian porque la primera se presenta natural y la segunda desnaturaliza la identidad de aquella, esto no asegura lógicamente que tal procedimiento no se haga re-naturalizando la propia identidad. Mignolo diferencia a ambas por un rasgo que solo asegura la desnaturalización de la identidad dominante. (p. 229)
} 
kantiana, retomando cierto legado foucaultiano (Rancière, 2014a, p.75 y 2004). Específicamente, la "crítica" rancieriana tiene el interés, no de buscar fundamentos, sino de dilucidar ciertas condiciones de posibilidad históricas que vuelven pensable y perceptible un orden de los cuerpos, los discursos y las prácticas; "un paisaje de lo común" y sus desplazamientos. Es ahí donde interviene la noción que nos interesa reconstruir:

Llamo reparto de lo sensible al sistema de evidencias sensibles que al mismo tiempo hace visible un común y los recortes que allí definen los lugares y las partes respectivas. Un reparto de lo sensible fija al mismo tiempo algo común repartido y ciertas partes exclusivas (Rancière, 2014, p.19).

En términos generales el concepto partage du sensible alude a los mundos perceptivos comunes y a la serie de divisiones y recortes, más o menos fijos, más o menos estables, que estos implican. Lejos de ser naturales o meramente dados, estos "sistemas de evidencias sensibles", remiten siempre a cierta configuración entre la experiencia sensible y sus modos de interpretación inteligible: "No hay para mí sensible en tanto que sensible. Lo que nos enseña Kant, es que hay sensibles. Un sensible siempre es una cierta configuración entre sentido y sentido, un cierto sentido de lo sensible" (Rancière, 2004, p.5). Se trata, en efecto, de regímenes de sensibilidad e inteligibilidad históricos y comunes, a partir de los cuales los sujetos aprehenden la realidad. Rancière insiste en que, estos marcos de percepción y comprensión en el cual se mueven los sujetos, constituyen siempre anudamientos de significaciones, formas de sentir, percibir, afectar y ser afectados que hacen sensible lo "real". Laura Quintana (2018), enfatizando en la diversidad de elementos constitutiva de todo reparto de lo sensible, propone pensarlos como "ensamblajes heterogéneos" de discursos, imágenes, enunciados y prácticas que distribuyen y trazan cierto sentido de lo sensible y de lo posible (p.452).

Estos anudamientos heterogéneos entre formas de percepción y modos de inteligibilidad implican siempre "un recorte de los tiempos, y de los espacios, de lo visible y lo invisible, de la palabra y el ruido" que configura una repartición (orden y 
distribución) de los cuerpos, las palabras y las cosas en un paisaje común (Rancière, 2014, p.20). Para Rancière lo sensible está siempre distribuido, dividido o repartido. Como han señalado distintos traductores de su obra, la palabra partage lleva inscripta esta ambivalencia ya que puede traducirse a la vez como "compartir" "participación" y/o como "partición", "división" o "distribución". A Rancière esta ambigüedad le sirve porque su noción de partage du sensible designa al mismo tiempo cierto común compartido a la vez que alude a recortes y líneas divisorias que demarcan una participación diferencial entre las partes en ese tejido de lo sensible. Como señala Federico Galende, esta perspectiva le permite esbozar una filosofía materialista que atiende a las distribuciones de lo sensible, a cómo se reparten: espacios, tiempos, prácticas, acciones, palabras, capacidades, recursos y saberes, sin suponer ningún fundamento (arkhé) ontológico a las mismas, ni algún tipo de necesidad histórica (2012, p.25). El materialismo rancieriano se compatibiliza con la afirmación de la contingencia histórica de las distintas distribuciones de lo sensible y con un método "estético-cartográfico" (Quintana, 2018) que propone mapear las condiciones de los repartos: bajo qué tecnologías, discursos y dispositivos de poder específicos se distribuye lo "sensible" y qué prácticas abren los momentos de sus re-distribuciones.

Esta noción lleva a Rancière a pensar las formaciones sociales como cierta distribución diferencial de los cuerpos en tiempos, lugares, ocupaciones e identidades y capacidades, fijadas y estabilizadas (policía) o puestas en cuestión y alteradas (política) a partir de prácticas de subjetivación. Ahora bien, esto no implica que debamos pensar que un reparto de lo sensible es una estructura externa que "capta" a los cuerpos y los distribuye en el tejido social, sino que justamente la noción busca plantear cómo ciertos anudamientos entre formas de sensibilidad e inteligibilidad "consensuan" o tejen en la trama sensible de lo social, con mayor o menor cohesión y consistencia, las formas de participación de los cuerpos en la comunidad según maneras de ser y hacer, y cómo estos límites son siempre pasibles de ser alterados por prácticas que los des-anuden y re-configuren de otros modos.

Lo que interesa a Rancière es, entonces, la "lógica" que opera en los modos sociales de ser-en-común. En El desacuerdo (2010) el argelino-francés distingue la 
lógica "policial" de la lógica "política" como dos formas de re-partir lo sensible que operan en cualquier formación social (p.42). La lógica policial, se caracteriza por intentar imponer un ordenamiento estable entre las partes de la comunidad en la cual no hay vacío ni suplemento. Para Rancière la esencia de la policía no es la represión, ni el control sobre lo vivo de los aparatos del Estado, sino una repartición de lo sensible que busca saturar el campo de lo posible a partir del consenso en torno a lo que los sujetos son, sus lugares y ocupaciones diferenciales y lo que pueden:

La policía es primeramente un orden de los cuerpos que define las divisiones entre los modos del hacer, los modos del ser y los modos del decir, que hace que tales cuerpos sean asignados por su nombre a tal lugar y a tal tarea; es un orden de lo visible y lo decible que hace que tal actividad sea visible y que tal otra no lo sea, que tal palabra sea entendida como perteneciente al discurso y tal otra al ruido. (Rancière, 2010, p. 44)

Esta serie de distinciones y distribuciones policiales de lo común, a la vez que establece que cada parte tiene la parte que le corresponde, que no hay parte sin parte, produce en el mismo acto una serie de exclusiones, un agravio (tort) al negar la igual capacidad de cualquiera de participar de una parte que no le corresponde. Toda distribución social -generalmente implícita- de los cuerpos según identidades, lugares ocupaciones y roles establece un juego de competencias o capacidades que distribuyen, demarcan y estabilizan en lo común una serie de jerarquías y funciones entre los sujetos, delimitando ciertas partes exclusivas/excluidas. Jerarquías, exclusiones y legitimaciones múltiples: clase, género, raza, ocupaciones, capacidades, saberes etc., pero que reproducen una partición desigual fundamental entre aquellos cuya palabra (logos) "tiene parte" para ocuparse plenamente de los asuntos de la comunidad y aquellos seres que son expulsados "a la noche del silencio o al ruido animal de las voces que expresan [solo] agrado o sufrimiento" (Rancière, 2010, p.36).

La policía es, entonces, una estructuración de un mundo perceptivo común donde la subordinación de unos cuerpos y la delegación de sus capacidades de pensar y decidir en torno a los asuntos comunes aparecen fundadas como una evidencia 
sensible. Su lógica desigualitaria opera ensamblando a los cuerpos con identidades y ocupaciones: maneras de ser, de hacer, de pensar y decir que los fijan en lugares y tareas respectivas, buscando estabilizar y naturalizar en el campo social, lo posible, lo que es pensable y realizable por esos cuerpos, a partir de lo que se suponen que son (Rancière, 2006, p.71).

Es preciso señalar que para Rancière hay distintas policías, que tienen mecanismos y formas de repartición diferentes, algunas con mayores inscripciones igualitarias que otras, aunque comparten el intento de estabilizar una distribución desigual de los cuerpos y las capacidades como una cuenta exacta, sin resto ni suplemento. Esto nos lleva a plantearnos: ¿es posible pensar la colonialidad como un reparto de lo sensible policial? ¿qué implicancias o consecuencias tendría establecer este vínculo? ¿puede ayudarnos a pensar de otro modo la sujeción colonial y darnos otra mirada sobre las prácticas de des-sujeción?

Para intentar abordar estos interrogantes proponemos brevemente detenernos y recuperar algunas formulaciones de Aníbal Quijano en torno a la colonialidad, que ahonden lo expuesto en nuestro primer apartado. En su artículo "Colonialidad, modernidad/racionalidad" (1992), donde por primera vez introduce este concepto, el peruano afirma:

Empero, la estructura colonial de poder produjo las discriminaciones sociales que posteriormente fueron codificadas como "raciales", étnicas, "antropológicas" o nacionales", según los momentos, los agentes y las poblaciones implicadas. Esas construcciones intersubjetivas, producto de la dominación colonial por parte de los europeos, fueron inclusive asumidas como categorías (de pretensión "científica" y "objetiva") de significación ahistórica, es decir como fenómenos naturales y no de la historia del poder. (p. 12)

En este texto pionero, Quijano sostiene que la dominación colonial (lo que luego llamará la "colonialidad del poder") se asienta a partir de establecer un marco de relaciones entre distintas identidades que las clasifican y valoran desigualmente. Como destaca, la eficacia de estas clasificaciones sociales es que las mismas se proponen 
como naturales, "científicas" o a-históricas: se proponen como evidencias sensibles. Es interesante marcar que, para el autor, este marco de "discriminaciones sociales" no es una consecuencia o un fenómeno a posteriori de la colonialidad, sino que es el operar mismo de su lógica. La colonialidad del poder es para Quijano una estructura específica de dominación global, que emerge con la Conquista de América y cuyo fundamento es cierta distribución desigual de los cuerpos, recursos y formas de explotación del trabajo, según un sistema de clasificación social: una jerarquía de las identidades que se hace pasar por legítima y natural.

Como destacan Restrepo y Rojas, otro de los aspectos importantes de este artículo radica en señalar que este marco desigual y valorativo de las identidades es interiorizado aún por aquellos colonizados (2010, p.95) Si bien para estos autores hay aquí una idea de "colonialidad cultural" que en los estudios decoloniales no ha sido explorada, a nosotros nos interesa hacer énfasis en que para Quijano esa repartición colonial no es meramente una estructura exterior y ajena a los cuerpos que se les impone, sino que si logra asentarse es porque performa ciertas modalidades de sentir y pensar de los propios colonizados, que hacen que ciertos bienes y formas culturales sean percibidas como deseables o indeseables, que ciertas identidades y modos de hacer sean vistas como superiores.

En este primer artículo no aparece aún la importancia capital de la cuestión racial para Quijano. En textos posteriores y esenciales del autor (1998, 2000 y 2007), vemos como uno de los puntos recurrentes y permanentes de su conceptualización de la colonialidad es pensar que esta lógica de repartición y valorización social se asienta sobre el dispositivo de la raza:

En la medida en que las relaciones sociales que estaban configurándose eran relaciones de dominación, tales identidades fueron asociadas a las jerarquías, lugares y roles sociales correspondientes, como constitutivas de ellas y, en consecuencia, al patrón de dominación colonial que se imponía. En otros términos, raza e identidad racial fueron establecidas como instrumentos de clasificación social básica de la población. (Quijano, 2000, p.122) 
El desplazamiento e hincapié en la cuestión de la raza y la racialización de las relaciones sociales le va a permitir a Quijano profundizar en la comprensión del modo en que operó la lógica colonial a partir de la conquista de América. Para el autor la idea de raza aparece como el primer gran dispositivo colonial de repartición de los sujetos en posiciones sociales, organización de la fuerza de trabajo y legitimación de la imposición de saberes, creencias y conductas. Por supuesto que no podemos aquí explayarnos con profundidad sobre esta cuestión (y menos aún analizar si es justificado el lugar privilegiado que tiene la raza sobre otras tecnologías de poder colonial), pero basta para nuestro interés señalar que el dispositivo de la raza anuda y establece una correspondencia entre los rasgos fenotípicos de los cuerpos, el color de piel y el lugar de origen de los sujetos, con supuestos ethos y capacidades que los ubicarían en ciertas posiciones sociales. ${ }^{7}$ El dispositivo de la raza configuró en las distintas colonias un sistema de clasificación jerárquico y complejo que organizaba el campo social en un sistema de identidades (negros, mulatos, indios, mestizos, blancos, etc.), capacidades y posiciones respectivas. De este modo, condujo a plantear una distinción y superioridad de orden biológico, étnico, religioso, epistémico y político entre los europeos y no europeos.

Entendemos que este breve repaso por las ideas de Quijano nos permite sostener la posibilidad de pensar la colonialidad en términos de reparto de lo sensible. El énfasis que el sociólogo peruano hace en el carácter clasificatorio de la colonialidad, al entenderla como una estructura de dominación basada en una distribución diferencial y desigual de los sujetos en funciones, trabajos y posiciones según un modelo racial, parece absolutamente compatible con la noción rancieriana de reparto policial que reconstruimos arriba. Quijano destaca que la lógica colonial operó a partir de dispositivos, estrategias y prácticas de racialización, generización e identificación que configuraron/an una repartición sensible de los cuerpos al interior de los distintos órdenes locales y también a escala global. Del mismo modo, para Rancière el poder

\footnotetext{
7 Puede decirse que el dispositivo de la raza, más allá de sus funcionamientos específicos en los diferentes contextos coloniales, es un anudamiento entre ciertos datos sensibles (color de piel, lugar de origen) y cierta interpretación de los mismos (capacidades, ocupación) que configura lo que Rancière llamaría un "sistema de evidencias sensibles", donde se asienta en lo común una repartición desigual de los lugares sociales.
} 
policial y sus formas de sujeción operan distribuyendo, clasificando y marcando límites entre los lugares/tiempos que corresponden a los cuerpos, sus supuestas capacidades y posibilidades.

Como sugiere Quijano la colonialidad del poder logró su eficacia a partir de postular sus distinciones sociales como dadas, buscando naturalizar esta repartición en las subjetividades y los cuerpos de los propios subordinados. Por su parte, la noción de reparto de lo sensible al hacer hincapié en cómo las formas de tener parte se arraigan en modalidades perceptivas, contribuye a pensar una dimensión estética de la colonialidad: esta no se trata meramente de un andamiaje estructural, de formas institucionales o de imposición cultural, sino también de modalidades de sensibilidad y afectividad que hacen aceptable un orden de múltiples desigualdades. En efecto, el énfasis que Rancière pone en lo sensible nos permite pensar que si estos dispositivos coloniales tuvieron y aún tienen efectividad es porque configuran "la regla del aparecer" de los cuerpos (2010, p.45), es decir, un mundo perceptivo; un orden de visibilidad y un modo de inscripción de los cuerpos en el tejido social, de acuerdo a lo que se supone que son y a la "evidencia" de lo que pueden. Los dispositivos y tecnologías coloniales (como la raza) buscan determinar qué y cómo los cuerpos son visibles, qué voces son audibles, qué afecta y qué conmueve, es decir, qué se mantiene en el campo de lo sensible y qué no (y cómo) ${ }^{8}$.

Ahora bien, entendemos que la metodología rancieriana se aleja claramente del intento sociológico de Quijano de brindar una teoría que explique y busque determinar el funcionamiento de la colonialidad del poder como una macro-estructura social. La noción de "reparto de lo sensible" rechaza buscar por detrás de estos anudamientos entre formas de percibir, ver, pensar que conforman un paisaje de lo común y sus distribuciones, una lógica causal subterránea, una racionalidad "oculta" que el intelectual crítico debería descifrar para explicar su totalidad. Para Rancière en cada formación social podemos encontrar distintas formas en que lo sensible es repartido y estas líneas no solo son múltiples e irreductibles a una lógica, sino que

\footnotetext{
${ }^{8}$ Esta atención a la dimensión estética inscripta en la noción de partage du sensible permite a resaltar el rol de la sensibilidad y la afectividad tanto en la construcción de un orden de la dominación colonial como en las posibilidades de su alteración.
} 
están en permanente movimiento. En este sentido, su pretensión teórica es más modesta: se trataría de cartografiar los distintos repartos coloniales, pensados -más que como un patrón o una matriz- como "ensamblajes heterogéneos" de tecnologías y dispositivos de poder, más o menos articulados, que buscan performar marcos de comprensión, percepción y afección específicos en los cuales los sujetos se mueven, sienten y actúan. Esto sugiere la posibilidad de pensar que hubo y hay distintas lógicas coloniales que, bajo distintos dispositivos y estrategias, establecieron distintas modalidades de subordinaciones y sujeciones en las diversas sociedades de Nuestra América 9 .

Otra de las consecuencias que tiene pensar la colonialidad en términos de repartición de lo sensible, es la necesidad de cuestionar la reivindicación identitaria como política decolonial. La colonialidad en su estructuración desigualitaria, lejos de excluir las diferencias, las articula y subordina a cierta distribución de lugares respectivos. Anuda una cierta relación entre lo común y lo diferente, donde a cada diferencia le corresponde una identidad exacta, un lugar y una capacidad definida. Lo que buscan neutralizar los repartos coloniales no es propiamente la "diferencia", sino todo suplemento a esta cuenta exacta y clasificada de las partes de la comunidad. Excluye toda posibilidad de una diferencia que difiera a sí misma, toda mixtura, toda impureza -todo entre- que implique sujetos que se desplacen de sus lugares y funciones asignadas, que unan sus nombres a otras capacidades y pongan en cuestión sus roles y posiciones sociales (Rancière, 2006, p.71).

Si entendemos que los repartos coloniales se constituyen a partir de dispositivos identitarios que distribuyen los cuerpos en un orden jerárquico de visibilidades y capacidades, la reivindicación de la diferencia colonial y de la "identidad en la política" que sostiene Mignolo lejos de tener un potencial descolonizador, es parte del juego binario de lo "propio" / "impropio" que ha servido para configurar y estabilizar estos órdenes desigualitarios que delimitan lo que los sujetos pueden. En una entrevista Rancière sostiene:

\footnotetext{
${ }^{9}$ En este sentido, creemos que esta perspectiva se acerca a lo que sostiene Castro-Gómez en su lectura foucaultiana de la colonialidad; "No hay una 'colonialidad del poder' sino que hay muchos dispositivos coloniales cuyo análisis dependerá del nivel de generalidad que se esté considerando (micro, meso o macro), así como de su ámbito específico de operación" (Castro-Gómez, 2019, p.13).
} 
Se olvida demasiado rápido, por ejemplo, la sutilidad de las formas de exclusión que emergen de la historia colonial. En las legislaciones coloniales, las razones por las que los derechos políticos de los colonizados se veían negados, se apoyaban también en el respeto por su especificidad." (Rancière, 2011, p. 109)

En efecto, la articulación que propone Mignolo entre un modo de ser, su lugar de enunciación, su supuesta experiencia y potencia constituye una suerte de estabilización y ubicación policial de los sujetos colonizados en un espacio, una identidad y una forma de pensar, que reproduce la lógica colonial de lo "propio" y su agravio (tort) a la igualdad de cualquiera de apropiarse de otras formas de ser y pensar. Es preciso, entonces, poner en cuestión la manera en la que el argentino piensa la descolonización: quizás esta no consista en el movimiento de resituar una voz, en un cuerpo y en un lugar, sino justamente en prácticas que busquen interrumpir y desestabilizar esta correlación entre ser, lugar, pensar y hacer.

\section{Emancipación y decolonialidad: el problema de la "apropiación" en la Revolución} haitiana.

Al pensar la sujeción en términos de "reparto de lo sensible" Rancière se cuida de hacer de las relaciones de poder y de la dominación "una bestia magnifica" de la que es imposible escapar: estos límites policiales que buscan estabilizar lo que los cuerpos pueden, lejos están de saturar el campo de la acción. Su mismo carácter de articulación de elementos heterogéneos entraña la posibilidad de com-poner otras relaciones, de abrir ciertas brechas (écarts) y disyunciones entre lo visible y lo pensable, entre lo que se espera de un cuerpo y lo que puede (Rancière 2014a, p. 95). No caben dudas de que el interés principal de los textos de Rancière es seguir el hilo de aquellas experiencias de emancipación (individuales o colectivas) que lograron desestabilizar un reparto de lo sensible desplazando estos límites. En este sentido, desde La nuit des prolétaires, busca investigar aquellas prácticas concretas e históricas 
a partir de las cuales los sujetos fueron capaces de reconfigurar un orden sensible determinado, a partir de abrir líneas de fracturas que recusen tales particiones. (2014a, p. 58,59)

A las prácticas colectivas que alteran un reparto social de lo sensible el autor las llama procesos de subjetivación política. La exploración histórica en torno al movimiento obrero, llevó a Rancière (2010a) a pensar que estos procesos no implican la toma de conciencia de ciertas determinaciones económicas, sociales o el reconocimiento y asunción de una identidad, sino más bien una dinámica y un poder de desidentificación y desclasificación de su modo de ser y el lugar socialmente asignado. Los proletarios parisinos de 1830 se apropiaban del tiempo de la noche, habitualmente destinado al reposo, para dedicarlo a ensoñaciones colectivas, reuniones de estudio, lecturas, la producción de periódicos, folletos y poesía, en definitiva, al acceso al mundo de la palabra literaria y política. Imitando las formas "burguesas" en sus propios dispositivos de lucha, realizaban un trabajo de desacomodo en relación a cierta "distribución de lo sensible" que solo concebía sus capacidades como trabajadores manuales, a la vez que demostraban en la práctica una igualdad negada por sus patrones.

¿Puede ser fructífero recuperar el modo en que Rancière tematiza la emancipación para pensar la decolonialidad? ¿Es posible pensarla como movimiento de des-identificación y práctica de la igualdad? ¿No nos conducirá acaso a la asimilación del colonizado a la cultura del colonizador reproduciendo cierta "colonialidad del saber"? ¿No fue acaso el ideal de igualdad un principio moderno que encubrió un orden de violencias y desigualdades?

Para intentar explorar estos interrogantes proponemos retomar ciertas prácticas de los insurrectos negros en la Revolución haitiana ${ }^{10}$. Proponemos partir, entonces, de la siguiente escena.

\footnotetext{
${ }^{10}$ Desde ya advertimos que no intentamos aquí hacer una suerte de aplicación del esquema teórico de Rancière a una serie de prácticas, menos aún proponerlo como el "modelo" que estas deben seguir. Más bien, nos interesa sugerir que estas prácticas de descolonización parecieran entrar en diálogo y desplegar por otros caminos algunas exploraciones teóricas que el argelino-francés trazó a partir de su inmersión en los archivos obreros del siglo XIX.
} 
Los ex esclavos de Haití se tomaron las consignas revolucionarias francesas incluso más literalmente que los propios franceses (...) Esto condujo a sublimes momentos "comunistas», como el que se produjo cuando los soldados franceses (enviados por Napoleón para sofocar la rebelión y restaurar la esclavitud) se aproximaron al ejército negro de (auto) liberados esclavos. Cuando oyeron un rumor poco claro procedente de la multitud negra, los soldados pensaron al principio que debía ser alguna clase de canto tribal, pero cuando llegaron más cerca se dieron cuenta de que los haitianos estaban cantando la Marseillaise, y empezaron a preguntarse a voces si no estaban luchando en el bando equivocado. (Zizek, 2011, p.130)

Entendemos que esta escena, que Slavoj Zizek re-elabora a partir de un pasaje de Susan Buck-Ross, ilustra de un modo ejemplar la tesis sostenida en el ya clásico Los jacobinos negros de C.R.L James y en un texto más reciente del pensador argentino Eduardo Grüner (2010) dedicado a pensar la gesta haitiana. Entre las ideas centrales de estos estudios se encuentra el protagonismo de los esclavos en el proceso revolucionario que culminó con la Independencia de Haití hacia 1804 y la singular apropiación que hicieron del legado de la Revolución Francesa para oponerla a los propios franceses y desestabilizar el orden colonial. De este modo, el movimiento de liberación y descolonización de los esclavos haitianos, lejos de tratarse de un desprendimiento del legado europeo, implicó un peculiar trabajo de apropiación del mismo. Como sostiene Grüner (2010):

Apareció una situación extraordinariamente interesante: los afroamericanos (en Haití sobre todo a través del lúcido pensamiento político de Toussaint Louverture) se apropiaron de ese "universalismo" de la Declaración de los Derechos del Hombre y del Ciudadano -documento central emanado de la gran Revolución metropolitana-, y mediante ese gesto de apropiación desnudaron el carácter ideológico. (p.275)

El argentino en su reconstrucción del acontecimiento haitiano y en la serie de reflexiones teóricas que va hilvanando, advierte dos aspectos que nos resultan interesantes: sin la Revolución Francesa detrás y la difusión de sus principios de 
libertad e igualdad hacia las costas de Santo Domingo no hubiese sido posible el "salto cualitativo" que transformó las revueltas de esclavos en un proceso revolucionario. Al igual que C.R.L. James, ubica al acontecimiento francés como una de las condiciones de posibilidad de la radicalidad de la gesta haitiana (James, 2003). Ahora bien, para ambos esta revolución fue "más francesa que la francesa" porque universalizó hacia los esclavos los principios modernos, constituyendo "la más radical respuesta a los falsos 'universalismos' filosófico-políticos" (Grüner, 2010, p.290). En este sentido, Grüner insiste en que, mediante la apropiación del legado europeo y sus principios, los esclavos desnudaron su falsedad "ideológica", es decir, desenmascararon el universalismo abstracto propio de los ideales de la Revolución Francesa.

Entendemos que desde algunas exploraciones de Rancière podemos proponer otra lectura de esta apropiación. Podríamos sugerir que quizá el uso que hicieron los esclavos de la Declaración de los Derechos del Hombre y el Ciudadano no puede restringirse a poner en evidencia su formalidad, el carácter abstracto o "falso" de estas declaraciones. Más que un movimiento que busca desenmascarar el carácter ideológico de los principios, puede ser pensado como un intento de verificarlos de manera polémica, intento que puso en juego una dinámica de la igualdad como potencia de desclasificación del rol que el reparto de lo sensible colonial adjudicaba a los negros, y lejos de demandar una mera inclusión en el mismo, lo reconfiguró.

En la genealogía de la emancipación obrera que Rancière rastrea en el siglo XIX, el vínculo entre desidentificación de lo propio y apropiación de lo impropio, es crucial. Si la sujeción policial es ante todo la imposibilidad de ser otra cosa a la que se supone que se es, la incapacidad de moverse de las formas de ver, pensar y hacer asignadas, las prácticas de des-sujeción tienen que poner en juego un movimiento de alteración de esta identidad y una demostración de una capacidad. Y es justamente a partir de la apropiación de las palabras, los usos y la cultura de los otros, de aquello que supuestamente no le pertenece, que un sujeto puede des-identificarse y desclasificarse del lugar asignado. Rancière destaca que una desidentificación implica a la vez la interrupción y ruptura de una identidad tal como era cifrada en un orden de posiciones existentes y la puesta en movimiento de la capacidad de apropiarse de 
otros modos de decir, hacer y pensar a fin de construir nuevas subjetividades, nuevas formas de visibilidades y sensibilidades.

Es preciso aclarar que para Rancière la des-identificación no es un mero despojo de la propia identidad, sino que es siempre una reconfiguración de la misma que se gesta en este juego de apropiaciones de lo impropio y des-apropiaciones de lo propio. En la escena propuesta arriba, el "acontecimiento" se produce cuando los esclavos cantan el himno revolucionario francés. Es el desplazamiento entre el canto tribal previsible y la Marselleise la praxis que produce la perplejidad de los colonizadores, ya que esta apropiación des-anudaba el arreglo identitario y racial que el reparto colonial establecía entre lo que los esclavos negros supuestamente son y lo que supuestamente pueden. En su texto Grüner (2010) nos brinda otro ejemplo:

Como puede verse en la iconografía de la época, los líderes del nuevo estado se vestían y adornaban como "reyes" o "emperadores", de la misma manera que durante la revolución se habían vestido como generales o mariscales del ejército francés (...) Y era entonces esa conjunción impensable, inconcebible -tanto como hemos visto que lo era la Revolución haitiana misma- entre el brillante y colorido uniforme (no digamos ya el "título de nobleza") de general, mariscal o emperador, y la piel negra -piel de esclavo normalmente desnuda o a lo sumo "vestida" con andrajos sucios e informes- lo que producía una disrupción semiótica. (p.324)

La utilización de las prendas brillantes y coloridas del amo por parte de los líderes negros no produce una imagen-copia, sino más bien una imagen excesiva, una "conjunción impensable, inconcebible". Es decir, este gesto de vestirse como los otros, de apropiarse de las formas del colonizador, es una práctica que abre una brecha entre las identidades: una reconfiguración de las mismas. Esta imagen y la propuesta por Zizek ilustran muy bien cómo la apropiación produce mixturas singulares, sujetos "anfibios", un nos-otros (nous-autres) no identificable previamente en el espacio social: una "identidad imposible" -en términos de Rancière- que permite desestabilizar las fronteras y límites que los dispositivos de repartición coloniales establecían como evidentes. 
En este sentido, si la colonialidad opera a partir de dispositivos identitarios, la descolonización, por tanto, lejos de ser la mera afirmación de lo propio, pareciera ser una operación simbólica y práctica por la cual un nombre cualquiera se desidentifica de su imagen, se desincorpora de su habitus y se desplaza de los tiempos/lugares asignados por el orden colonial (Rancière, 2010, p.53). Esto supone que los sujetos, a partir de diversas prácticas problematicen su "diferencia colonial", su supuesto lugar "propio" y aquellos dispositivos identitarios e imágenes que los hacen reconocerse como una parte determinada de la distribución dada.

Grüner lee también, en este gesto de apropiarse de las vestimentas de los franceses, una demostración de la igualdad:

Se trataba, en última instancia, de demostrar -y demostrarse- que los ex esclavos podían igualarse a sus antiguos amos en su propio terreno (el de la guerra y la política), contra la inferiorización, incluso la "animalización", a que estos los habían sometido durante siglos. (Grüner, 2010, p.325)

Si los dispositivos de repartición dañan la igual capacidad de los sujetos de hacer otra cosa a lo asignado, según un arreglo entre modos de ser, hacer y pensar, es evidente que la desclasificación y la apropiación de las capacidades supuestamente no correspondidas son movimientos que ponen en acto esa igualdad negada. En efecto, para Rancière, la igualdad es la afirmación práctica de una capacidad que desarregla cualquier vínculo que ate a un cuerpo a un determinado modo de ser y que lo localice en lugar respectivo. (Rancière, 2015, p.33) De este modo, la afirmación de la capacidad de cualquiera (n'importe qui) neutraliza el juego de asimetrías y divisiones del orden policial y abre a que cualquiera pueda apropiarse de un decir, un hacer y un pensar, una capacidad que no le correspondía, abriendo líneas de fugas de su lugar específico. La igualdad rancieriana lejos de poseer contenidos específicos, supone un vacío, un principio anárquico que desanuda las distribuciones a partir de la cual funciona la lógica policial: "La esencia de la igualdad no consiste tanto en unificar como en desclasificar, en deshacer la supuesta naturalidad de los órdenes para reemplazarlas por figuras polémicas de la división". (2010b, p.52) 
En el caso de la Revolución Haitiana es indudable que la apropiación del lenguaje de los derechos fue fundamental para la gesta revolucionaria. Esta apropiación del lenguaje de los otros, de la lengua del amo, hizo posible, por un lado, la desclasificación de ciertos sujetos como esclavos, y una demostración práctica de la igualdad, como prueba de sí y reclamo a los otros.

En su artículo, "Who Is the Subject of the Rights of Man?" (2004), Rancière, alejándose de tradición marxista, señala que las inscripciones igualitarias de los Derechos del Hombre y el Ciudadano o los preámbulos de la Constituciones modernas no son meras formas, ilusiones o abstracciones, sino que son escrituras que "forman parte de la configuración de lo dado, que no consiste solo en una situación de desigualdad, sino que también contiene una inscripción que otorga a la igualdad una forma de visibilidad" (p. 302, trad. nuestra). A partir de 1789 estas "escrituras" comienzan a ser parte del entramado heterogéneo de elementos que compone un reparto de lo sensible en las sociedades Occidentales. En este sentido, pueden asumirse como premisas de una argumentación y una práctica política; la igualdad y la libertad común, como inscripciones en lo sensible, a partir de las cuales los sujetos pueden apropiarse para contraponerlas a las múltiples negaciones específicas. Esta contraposición, habitualmente planteada en términos de contradicción entre el "derecho formal" y la "realidad efectiva", puede asumir una forma que no busque la desmitificación de los principios del derecho, sino su verificación.

La frase igualitaria no es simplemente una pura nada. Una frase posee el poder que se le confiere. Ese poder es antes que nada el poder de crear un lugar en el que la igualdad pueda reclamarse de ella misma: en alguna parte hay igualdad; está dicho, está escrito. Y por lo tanto puede ser verificado. (Rancière, 2010b, p.67)

Para Rancière las formas de subjetivación política, tal como pueden rastrearse en muchas revueltas y luchas sociales, constituyen un uso subjetivante de los derechos para crear escenas de litigio sobre qué implican esos derechos, a quiénes afectan y a 
quiénes incluyen. Esta dinámica pone en juego una suerte de verificación de la igualdad. Esto no implica que necesariamente los sujetos se reúnan en sus reclamos para "verificar la igualdad". Más bien, supone que al tratar el agravio (tort) de ser subordinados de alguna manera y estar excluidos de la posibilidad de pensar y participar en los asuntos comunes, estos ponen en movimiento una serie de prácticas y objetivos específicos que presuponen, a veces implícitamente y otras no, la afirmación igualitaria: somos igualmente capaces que cualquier otro de discutir acerca de lo común (Rancière, 2014a p.165). Esta igualdad como presupuesto que es preciso verificar, tiene su manifestación en términos políticos en la necesidad de poder coimplicar una relación de fuerzas con lo que Rancière llama una "práctica demostrativa", que bajo un "sistema de razones" a la vez que se denuncia la arbitrariedad de la desigualdad en los hechos, demuestre (también en los hechos) que quienes la reclaman comparten la capacidad común de pensar, discutir, argumentar no sólo el perjuicio específico que los afecta, sino también sobre qué orden es deseable y posible (Rancière, 2010b, p.68). La igualdad constituye, entonces, un trabajo doble: demanda y presión a los otros, pero sobre todo implica un trabajo de sí, una prueba que los sujetos se imponen a sí mismos de constituirse iguales a cualquier otro.

En este sentido, Rancière investigó cómo el movimiento obrero francés del siglo XIX Ilevó adelante una serie de actos y discursos que articulaban una relación de fuerzas con una práctica demostrativa de esta igualdad negada. Ante la igualdad proclamada por la ley y las prácticas desigualitarias de los patrones y el Estado, los obreros no rechazan como ilusoria la afirmación igualitaria, sino que se tomaron el trabajo de ponerla en acto y forzar formas de su reconocimiento que implicaron reconfigurar un reparto de lo sensible. Algunas décadas antes el referente más importante de la revuelta haitiana, se presenta en la escena pública sugiriendo este mismo movimiento: "Yo soy Toussaint Louverture, acaso mi nombre haya llegado a vuestros oídos. He emprendido la venganza. Quiero que reinen en Santo Domingo la libertad, la igualdad. Trabajo por hacerlas existir. Unios a nosotros". (James, 2003, p.126, sub. nuestro). En efecto, para Louverture la igualdad no implica solo un reclamo y una demanda, sino un trabajo, un conjunto de acciones y prácticas que la verifiquen 
en la realidad. Actos y palabras que prueben que esclavos y los colonizadores que son iguales, que la dominación colonial carece de fundamento. Tres años después, en 1796 cuando los españoles les ofrezcan a los revolucionarios armas en nombre del "rey" para combatir a los franceses, Toussaint y los generales negros rechazaran esta oferta señalando lo siguiente:

La libertad que los republicamos nos ofrecen, ustedes dicen, es falsa. Nosotros somos republicanos y en consecuencia, libres por derecho natural. La sola palabra "real" expresa todo cuanto hay de vil y mezquino en arrogarse el derecho de reducir a la esclavitud a hombres que son como los reyes y a quienes la naturaleza ha hecho libres (James, 2003, p.151)

Como se aprecia en esta declaración, para los revolucionarios no se trataba de contraponer la falsedad de la libertad a la realidad de la esclavitud, como un mecanismo desmitificador de los principios republicanos, sino más bien de oponer la realidad de la libertad y la igualdad a su no reconocimiento e incumplimiento en los hechos. Al apropiarse del lenguaje de los otros, del léxico republicano, demostraban no la falsedad de los principios igualitarios, sino la arbitrariedad de las prácticas que los niegan. Los esclavos haitianos trataron más bien de organizar un sistema de razones, de prácticas discursivas y no discursivas que sostengan la realidad de la igualdad y la libertad y de extraer las consecuencias que se siguen de esto. En este sentido, pusieron en juego no una mera protesta contra la igualdad negada, sino la construcción de otro mundo sensible donde nadie estaba destinado a la realidad de la esclavitud. Desafiaron el "sistema de evidencias sensibles" que el reparto colonial establecía. De este modo, a las relaciones de fuerza y las luchas militares contra los distintos ejércitos que pretendían volver a apretar las cadenas, los revolucionarios haitianos lograron articular esta lucha militar con un "sistema de razones" que se dirigía a los colonizadores como si escucharan, construyendo un mundo sensible común donde la igualdad sea el reclamo de cualquiera. Rancière sostiene: "Aquel que hace que como si el otro lo escuchara todo el tiempo su discurso, aumenta su propio poder y no solamente en el plano discursivo" (2010b, p. 71). 
Entendemos que en el proceso revolucionario haitiano se ve claramente como la apropiación del discurso y los símbolos de los colonizadores por parte de los colonizados fueron utilizados de un modo descolonizante porque permitieron un movimiento capaz de poner en crisis el anudamiento racial que establecía una evidencia entre el color de piel, la capacidad y el lugar social. A la vez implicó una demostración de igualdad que hizo posible poner en escena un desacuerdo político: "la contradicción de dos mundos alojados en uno solo: el mundo en que son y aquel en que no son, el mundo donde hay algo "entre" ellos y quienes no los conocen como seres parlantes y contabilizables y el mundo donde no hay nada" (Rancière, 2010, p.42). Los esclavos no se limitaron a reclamar su inclusión en el reparto colonial, sino transformaron las fronteras instituidas de este orden, logrando inscripciones de la igualdad siempre contingentes, cuya existencia no está garantizada más que en las formas y prácticas que intentan sostenerlas y extenderlas.

\section{A modo de conclusión.}

En su artículo "Geopolítica de la sensibilidad y del conocimiento: sobre descolonialidad, pensamiento fronterizo y desobediencia epistémica", Mignolo (2015) sostiene que ante la imposición de la lengua y la episteme moderna-occidental colonial, a los colonizados solo caben tres posibilidades: humillarse, asimilarse o desprenderse. Para el argentino esta última opción es la decolonial y consiste en una reafirmación positiva de la diferencia colonial de los condenados de la tierra: "Hay que dirigirse al reservorio de formas de vida y modos de pensamiento que han sido descalificados por la modernidad" (Mignolo, 2015, p. 177)

Intentamos seguir el hilo que articula su perspectiva geopolítica del saber con la idea de diferencia colonial para comprender esta posición. Vimos cómo a partir de este cruce el pensamiento de Mignolo configura un dispositivo identitario que entrelaza una correlación entre lugar, experiencia y pensamiento y con ello un principio de expresividad localizada: toda voz pertenece a un cuerpo situado en un lugar y tiempo determinado. De este modo, la perspectiva geopolítica de Mignolo rechaza un reparto 
que privilegia las voces eurocentradas e imperiales y llama a reconocer las epistemes y las palabras silenciadas de los damnés de la terre, como condición de articular una opción decolonial. Esta perspectiva, si bien revierte la valorización, se mantiene en la misma lógica que reparte (partage) las enunciaciones en un orden de los cuerpos, la experiencia y las capacidades en función de una territorialización de las voces. La misma resulta problemática porque pareciera reivindicar cierto privilegio epistémico de la diferencia colonial, al comprenderla como espacio (topos) y experiencia que hace posible un tipo de pensamiento decolonial, pero también porque lleva a pensar los procesos de descolonziación bajo la impronta de la identidad como movimiento de auto-afirmación de lo "propio" de los sujetos colonizados. El problema que vislumbramos es que difícilmente, si la colonialidad es una lógica estructurante y un sistema de clasificación de los sujetos en identidades, lugares y posiciones sociales, la mera afirmación de lo "propio" tenga demasiada eficacia para deshilvanar esa lógica.

Entendemos que la visión totalizante y unívoca de la Modernidad que la concibe solamente como la "otra cara de la Colonialidad" conduce a Mignolo a plantear la necesidad de un des-prendimiento de la misma. Rancière, por su parte, ha explorado ciertas líneas de fuga de la Modernidad como las trayectorias de Gabriel Gauny y Joseph Jacotot que hacen que difícilmente podamos reducirla a una lógica. Por otra parte, si entendemos la colonialidad como un "reparto de lo sensible" que articula diversos elementos, dispositivos y tecnologías, quizás podemos plantear otra alternativa. Desde la perspectiva rancieriana podríamos agregar una cuarta posibilidad a las planteadas por Mignolo: ante la imposición de la lengua y los saberes del otro, puede ser emancipador re-apropiarse de estos, como verificaciones polémicas de la igualdad. De una igualdad vacía y cuyas manifestaciones son siempre imprevisibles y experimentales, pero eficaces para desestabilizar la lógica desigualitaria que fija a los cuerpos en sus lugares. Como hicieron los esclavos haitianos, una práctica decolonial pone en movimiento la capacidad de desplazar los límites de lo que se supone que somos capaces de ver, escuchar, decir y pensar. Se trata de poder articular prácticas que expongan el reconocimiento de la capacidad de cualquiera de desear, trastocar y 
torsionar el saber del otro como forma de recusar y reconfigurar un orden colonial signado por múltiples desigualdades.

Esta alternativa nos permitiría indagar si los movimientos políticos que han luchado por la descolonización, aun cuando hayan sido considerados bajo una impronta identitaria, no es que han intentado romper con una lógica que ata sus cuerpos a un lugar determinado, a un ethos y un pensar. Preguntarnos si no es que han puesto en movimiento de diversas maneras, formas de creación y experimentación política que buscaron desmantelar un orden de los cuerpos, de los enunciados alineados con sus lugares e identidades. Quizás la emancipación en clave de desidentificación y prácticas de la igualdad pueda ser una perspectiva capaz de entrar en un diálogo fructífero con las revueltas decoloniales. 
Colonialidad, reparto de lo sensible y descolonización: una crítica rancieriana a la "opción decolonial" de Walter Mignolo

Bibliografía:

Blanco, J. (2009). Cartografía del pensamiento latinoamericano contemporáneo una introducción. Guatemala: Universidad Rafael Landívar.

Castro Gómez, S. y Grosfoguel, R. (Eds.) (2007). El giro decolonial. Reflexiones para una diversidad epistémica más allá del capitalismo global. Bogotá: Siglo del Hombre Editores.

Castro Gómez, S (2005a). La hybris del punto cero. Ciencia, raza e ilustración en la Nueva Granada (1750-1816). Bogotá: Editorial Pontificia Universidad Javeriana.

Castro Gómez, S. (2019) El tonto y los canallas. Notas para un republicanismo transmoderno. Bogotá: Editorial Pontificia Universidad Javierana.

Castro Orellana, R. (2020). El lado oscuro de la decolonialidad: anatomía de una inflación teórica. En Makaran G. y Gaussens P (coords). Piel blanca, máscaras negras. Crítica de la razón decolonial. México: Centro de Investigaciones sobre América Latina y el Caribe-Universidad Nacional Autónoma de México y Bajo Tierra Ediciones.

Curiel, O. (2007). Crítica poscolonial desde las prácticas políticas del feminismo antirracista. Revista Nómade, 26: 92-101. Colombia: Universidad Central.

Dussel, E (2003). Europa, Modernidad y eurocentrismo. En Edgardo Lander (comp.) La colonialidad del saber: eurocentrismo y ciencias sociales. Buenos Aires: CLACSO.

Franzé, J. (2013). Fisonomía de la metafísica decolonial: lo damné, una identidad sin narración. Tabula Rasa. 18: 229-251.

Galende F. (2012) Rancière. Una introducción. Buenos Aires: Quadrata.

Grüner, E (2010). La oscuridad y las luces Capitalismo, cultura y revolución. Buenos Aires: Edhasa.

James, C.R.L (2003) Los jacobinos negros. Toussaint L'Ouverture y la Revolución de Haití (Trad. Ramón García). México D.F: Fondo de Cultura Económica.

Ludmer, J. (2010). Aquí América Latina, una especulación Buenos Aires: Eterna Cadencia. 
Mezzadra S. y Neilson B. (2017) La frontera como método (Verónica Hendel) Madird: Traficantes de sueños

Mignolo, W. (2002) The Geopolitics of Knowledge and the Colonial Difference. The South Atlantic Quarterly 101(1):57-96.

Mignolo, W. (2003). Historias locales/diseños globales. Colonialidad, conocimientos subalternos y pensamiento fronterizo. Madrid: Akal.

Mignolo, W. (2005) La idea de América Latina, herida colonial y opción decolonial. (Silvia Jawerbaum y Julieta Barba, trads) Barcelona: Gedhisa

Mignolo, W. (2007). El pensamiento decolonial: desprendimiento y apertura. Un manifiesto. En Castro Gómez y Grosfoguel (eds.) El giro decolonial. Reflexiones para una diversidad epistémica más allá del capitalismo global (pp. 25-46). Bogotá: Siglo del Hombre.

Mignolo, W. (2007a) The de-colonial option and the meaning of identity in politics. Anales N. E. 9/10: 43-72.

Mignolo, W. (2010). Desobediencia epistémica II. Pensamiento independiente y libertad De-colonial. Revista Otros Logos, 1:8-42.

Mignolo, W. (2015) Habitar la frontera Sentir y pensar la descolonialidad (Antología, 1999-2014). Barcelona: CIDOB y UACJ.

Pimmer, S. (2017) Gramsci y su lugar de enunciación: una crítica a la geopolítica del conocimiento de Walter Mignolo. Revista Observatorio Latinoamericano y Caribeño 1(1): 196-218.

Polo Blanco, J y Gómez Betancur, M. (2019) Modernidad y colonialidad en América Latina. ¿Un binomio indisociable? Reflexiones en torno a las propuestas de Walter Mignolo. Revista de Estudios Sociales 69: 2-13.

Quijano, A. (1992). Colonialidad y modernidad-racionalidad. Revista del Instituto Indigenista Peruano, 13(29): 11-20.

Quijano, A. (2000). Colonialidad del poder, eurocentrismo y América Latina. En Edgardo Lander (ed.), La colonialidad del saber: Eurocentrismo y Ciencias Sociales. Perspectivas Latinoamericana. (pp. 201-245). Caracas: CLACSO. 
Quijano, A. (2007) Colonialidad del poder y clasificación social. En Castro Gómez y Grosfoguel (eds.) El giro decolonial. Reflexiones para una diversidad epistémica más allá del capitalismo global (pp. 25-46). Bogotá: Siglo del Hombre.

Quintana, L. (2018) Más allá de algunos lugares comunes: Repensar la potencia política del pensamiento de Jacques Rancière. ISEGORÍA Revista de Filosofía Moral y Política, 59: 447-468.

Rancière J. (2014) El reparto de lo sensible: estética y política. (M. Padró, Trad) Bs. As: Prometeo.

Rancière, J. (2004) El uso de las distinciones. Traducción anónima de la intervención de Jacques Rancière en la jornada organizada en torno de la "partición de lo sensible" el 5 de junio de 2004 en el Colegio Internacional de Filosofía, a la iniciativa de Jean-Clet Martin, publicado en la revista Failles, 2, primavera 2006.

Rancière, J. (2004). ¿Who is the subject of the Rights of Man? South Atlantic Quarterly, 103: 2/3:297-310.

Rancière, J. (2006) Política, policía, democracia. (E. Tijoux, Trad) Santiago: LOM.

Rancière, J. (2010) El desacuerdo. Filosofía y política. (H. Pons, Trad). Buenos Aires: Nueva Visión.

Rancière, J. (2010a) La noche de los proletarios. Archivos del sueño obrero. (Emilio Bermini y Enrique Biondini) Bs. As: Tinta de Limón.

Rancière, J. (2010b) Los bordes de lo político. -2da edición. Trad. Alejandro Madrid. Bs. As. Ediciones La Cebra.

Rancière, J. (2011). El tiempo de la igualdad. Diálogos sobre política y estética. (J. Bassas Vila, Trad.). Barcelona: Herder.

Rancière, J. (2014a) El método de la igualdad. (P. Betesh Trad). Nueva Visión. Bs. As.

Restrepo, E. y Rojas A. (2010) Inflexión decolonial: fuentes, conceptos y cuestionamientos, Popayán: Universidad del Cauca.

Salvatore, R (2010) "A post-occidentalist manifesto". A Contra Corriente. Revista de Historia Social y Literatura en América Latina, 4(1): 126-138. 
Velázquez Castro, M. (2008). Las promesas del proyecto decolonial o las cadenas de la esperanza. Crítica y Emancipación. Revista Latinoamericana de Ciencias Sociales. 1/ 1: 253-263.

Žižek, S. (2011). Primero como tragedia, después como farsa (Amoroto Salido, Trad.) Madrid, Akal. 